\title{
Early Childhood Exposure To Literacy Skills As Better Predictor Of Reading Achievement: A Longitudinal Study From Ghana
}

\author{
Stephen Ntim (PhD; M.Phil; B.Ed; M.A) \\ Faculty of Education, Catholic University of Ghana \\ P.O. BOX 363, Fiapre-Sunyani, B/A Ghana, W/Africa \\ Email: stephenntim58@yahoo.com
}

\section{Doi:10.5901/jesr.2014.v4n6p379}

\begin{abstract}
This paper examined the correlation between early exposure to literacy skills in the homes at the Kindergarten level and later reading and phonological awareness at Primary One and Primary Two in Ghana. Young Children from educated home backgrounds exposed to alphabet knowledge, word recognition, nursery rhymes and lexical restructuring by their parents in the homes performed significantly higher in reading measures and phonological awareness than their counterparts from semieducated and non-educated backgrounds at the Primary level. Using Pearson correlation with significant at the 0.01 level (2tailed), this longitudinal study showed the synergy between early home background/economic/and parental educational status and later reading achievement of Ghanaian young children from the Kindergarten to the Primary level. These patterns of early disparities in childhood have the potential of carrying over into primary education and beyond that can affect the academic achievement as revealed by the findings of this longitudinal study.
\end{abstract}

Keywords: Early literacy skills; reading measures; phonological awareness; early childhood disparity

\section{Introduction}

The last decade has witnessed an unprecedented academic and political interest in early childhood educational programmes. These programmes seeking to promote early intellectual skills such as reading, computation and writing have been gaining popularity since the beginning of the millennium. For example in the US, the Bush Administration in 2002 endorsed the Head Start reforms. The focus was on building early academic skills emphasising that "on the first day of school, children need to know letters and numbers. They need a strong vocabulary. These are the building blocks of learning and this nation must provide them" (p. 12). The US National Research Council's Committee on the Prevention of Reading Difficulties in Young Children recommends providing environments that promote pre-literacy skills for all preschool children (Snow, Burns, \& Griffin, 1998). Similarly, the National Association for the Education of Young Children and the US National Council of Teachers of Mathematics (2002) issued a joint statement that advocated for high-quality mathematics education for children ages 3-6.

Over 30 governments now have national policies for Early Childhood Development and dozens more are being developed. In Ghana, for example, UNICEF was a strong advocate and supporter in the development of the national comprehensive policy on Early Childhood Care and Development (ECCD).

While most children in urban Ghana in the years before they enter school are likely to experience a supportive home and may have access to basic financial and nonfinancial resources that support healthy development and school readiness, many other children mostly from the rural parts of the country are not so fortunate. Recent global data from various sources illustrate some of these patterns of early disadvantage. More than a third of the world's countries with available data (56 out of 152) have very low pre-primary enrolment (Gross Enrolment Ratios (GERs) of below 30\%). Nearly half of them are in sub-Saharan Africa, where GER ranges from less than $1 \%$ in the Democratic Republic of Congo to $90 \%$ in Mauritius. Early Childhood Care Education (ECCE) is often provided by private institutions and is concentrated in urban and wealthy areas where parents tend to be more aware of its benefits and sensitive to the gender issue than rural ones. As a result, girls' access to ECCE is much better than to other levels of education. In some countries (Burkina Faso, Cape Verde, Comoros, Congo, Guinea-Bissau, Lesotho, Mauritius, Namibia and Zimbabwe) more girls are enrolled than boys (http://www.unesco.org/education/efa_report/zoom_regions_pdf/ssafrica.pdf). 


\section{Statement of Problem}

The first five years of life are critical to a child's lifelong development. Young children's earliest experiences and environments set the stage for future development and success in school and life. Early experiences actually influence brain development, establishing the neural connections that provide the foundation for language, reasoning, problem solving, social skills, behavior and emotional health.( Shonkoff and Phillips, 2002; Thompson, 2001). Families and communities play critical roles in helping children get ready for school. Children from families that are economically secure and have healthy relationships are more likely to succeed in school.

Globally, UNESCO report showed a worldwide learning crisis. Two hundred and fifty million $(250,000,000)$ children of school age cannot read or write, whether they are in school or out of school (http://www.unesco.org). In Africa learning achievement varies across countries. The Southern and Eastern Africa Consortium for Monitoring Educational Quality (SACMEQ), which conducted its latest assessment in fourteen countries in 2007, highlights acute deficits in learning achievement in several participating countries. In Malawi and Zambia, over a third of grade 6 students failed to acquire the most basic literacy skills. On the other hand, in mainland Tanzania around four in every five grade 6 students scored above level 4,3 and less than $4 \%$ had failed to achieve basic reading skills (http://unesdoc.unesco.org/images 10019/001913/191393e.pdf.).

In Ghana, reports from the Ministry of Education in 2008 (MOE: 2008) showed that in some parts of the country around one-half of young women and one-third of young men could not read a sentence even though they had spent six years in primary school. The School Education Assessment (SEA) examination was implemented for the first time in Ghana in July 2006 and was to be repeated in 2008. Approximately 515,000 students participated in the examination across the ten Regions. The Mathematics and English language examinations were administered to pupils in the Primary 2 and Primary 4. The results show that Primary 2 pupils had difficulty with listening comprehension and higher order analysis skills, particularly reading comprehension. Pupils encountered difficulties in reading a passage and answering questions where the answers were not directly in the text - but required a level of understanding and abstraction. Scores on these types of items showed that $40 \%$ to $50 \%$ of pupils were able to select the appropriate answers. In the Primary 2 mathematics test, pupils appeared to be learning basic addition and subtraction well. The results showed that more instruction time on multiplication, fractions and ordinal numbers is needed (see MoESS, 2008; Ghartey, 2010)

Given the fact that available research data in Ghana and in many African nations show learning deficits with literacy skills in the primary schools, it is important to find out the early home indicators likely to be the causes of reading difficulty. Besides, given the tremendous attention that early literacy has received recently in policy circles (Roskos and Vukelich, 2006), and the increasing diversity of children population, it is important to examine some critical dimensions of home precursors that are likely to offer some explanations to the challenge of conventional literacy.

\section{Objectives of the Study}

Based on the above defined problem, the following key objectives guided this research:

1) To investigate the specific home strategies that are likely to be successful in improving children's language and literacy skills during the preschool years and beyond.

2) To examine whether or not there is a synergy between early childhood literacy experiences and later reading acquisition. How are literacy and oral language related?

3) To study the types of home literacy activities that children are exposed to and how these early experiences contribute to early literacy and later reading acquisition.

4) To find out the relationship between socio-emotional development, and literacy development.

\section{Research Questions}

The key questions that this study investigated were:

1) What are the specific home strategies that are likely to be successful in improving children's language and literacy skills during the preschool years and beyond?

2) What is the relationship between early childhood literacy experiences and later reading acquisition? How are literacy and oral language related?

3) What types of home literacy activities are children exposed to and how do these early experiences contribute to early literacy and later reading acquisition? 
4) What is the relationship between socio-emotional development and literacy development?

\section{Significance of the Study}

This study is significant because of the reported crisis of reading and numeracy achievement in most public schools in Ghana. For example, Reading achievement levels as measured by the Government-administered Criterion Referenced Test in 2000 indicate that fewer than $10 \%$ of the school children at primary level six are able to read with grade level mastery(http://reading.org/downloads/international/092004_Ghana_summary.pdf). In some parts of Africa, such as Malawi and Zambia, over a third of grade 6 students failed to acquire the most basic literacy skills. (http://unesdoc.unesco.org/images/0019/001913/191393e.pdf.). The findings of this study therefore will help to underscore some of the precursors to conventional literacy that are linked to outcome in reading, as well as to identify some early weaknesses such as in oral language, phonological awareness, alphabet knowledge. Such findings will be of interest to the Ghana Education Service, educational psychologists, basic school teachers, day-care centres, parents and all other stakeholders in early child care education.

\section{Literature Review}

Research studies in early literacy programmes in the last decade have been concerned primarily on multiplicity of skills that serve as the foundation for reading and writing ability (Dickinson and Neuman, 2006; National Reading Panel Report, 2000; Neuman and Dickinson, 2001; Snow, Burns, and Griffin, 1998). For a child to become a skilled reader, he/she needs a rich language and conceptual knowledge base, a broad and deep vocabulary, and verbal reasoning abilities to understand messages that are conveyed through print. The following literature review on dimensions of language and literacy in early childhood is organised around these strands: language, phonological awareness, alphabet knowledge, prints concepts and background knowledge.

\subsection{Dimensions of Language and Literacy in Early Childhood}

\subsubsection{Language}

Verbal abilities are consistently understood to be the best predictors of later reading achievement (Scarborough, 2001). Skilled readers typically draw upon multiple levels of the language system (Dickinson, McCabe, Anastasopoulos, Peisner-Feinberg, and Poe, 2003), with abilities encompassing vocabulary, syntax, and discourse. Vocabulary size in optimal settings may increase exponentially in the early years (some estimate about seven words a day) (Snow et al., 1998), with children learning to comprehend words spoken to them before they are able to produce them on their own. Word knowledge, however, is not just developed through exposure to increasingly complex language, but to knowledgebuilding language experiences (Neuman, 2001) that involve children in developing and refining networks of categoricallyrelated concepts.

Children's sentences often start at two words (Bloom, 1970), but quickly lengthen to four or more words as children communicate their ideas increasingly through language. With word learning occurring so rapidly, children begin to make increasingly fine distinctions of words not only based on their meaning but also based on their sound. They begin to make implicit comparisons between similar sounding words, a phenomenon described by linguists as lexical restructuring (Goswami, 2001; Metsala, 1999). For example, a two-year old child probably knows the words "cat" from "cut;" "hot" from "not." Distinguishing between these similar sounding words both quickly and accurately, children begin to hear sequences of sound that constitute each known word.

\subsubsection{Phonological Awareness}

Phonological awareness describes children's sublexical awareness of (or sensitivity to) the phonological segments of spoken language, including words, syllables, rimes, and phonemes. Awareness at the word and syllable level is considered syllabic, or shallow, awareness, whereas awareness at the rime and phonemic level is considered subsyllabic, or deep, awareness (Anthony J et al, 2003). Phonological awareness tasks may include blending (e.g., blending the onset and rime of the word "splat"), segmenting (segmenting the onset from the rime of the word "splat"), or manipulating (moving the onset to behind the rime for the word "splat"). 
Based on a massive body of research (Burgess, 2006; Lonigan, 2006), phonological awareness is a critical precursor, correlate, and predictor of children's reading achievement. Discriminating units of language (i.e., words, segments, phonemes) is strongly linked to successful reading (National Reading Panel Report, 2000). It is, however, as described above, both a cause and a consequence of vocabulary development and learning to read (Ehri and Roberts, 2006). Typically developing children begin first to discriminate among units of language (i.e., phonological awareness), then within these units (i.e., phonemic awareness).

Evidence (Lonigan, 2006; Whitehurst and Lonigan, 1998) suggests that children achieve syllabic sensitivity earlier than they achieve sensitivity to phonemes, and sensitivity to rhyme before sensitivity to phonemes. Children's entry to these skills typically begins with linguistic activities such as language games and nursery rhymes (Maclean, Bryant, and Bradley, 1987) that implicitly compare and contrast the sounds of words, and include alliterative phrases (i.e., bibbily bobbily boo begins with /b/). Children must not only be able to recite and play with sound units, they must also develop an understanding that sound units map onto whole or parts of written language. Reviews and analyses for the last decade (Dickinson et al., 2003; Scarborough, 2001) have placed phonological awareness as a critical part of a complex braid of language abilities which include strands of phonology, semantics, syntax, pragmatics, and discourse. Its tie to children's ability to decode has been clearly established.

\subsubsection{Alphabet Knowledge (AK)}

Alphabet knowledge refers to children's knowledge of the individual alphabet letters in uppercase and/or lowercase formats. Knowledge of the alphabet letters is a strong predictor of short- and long-term reading success (Bond and Dykstra, 1967; Chall, 1990). However, its influence on later reading does not about know the letter names, per se. Rather, the learning of letter names mediates the ability to remember the sounds associated with the letters (Ehri, 1979). Once again, there is a reciprocal relationship between skills: Letter knowledge plays an influential role in the development of phonological awareness, and higher levels of letter knowledge are associated with children's abilities to detect and manipulate phonemes. Research (Gibson and Levin, 1975) indicates that children differentiate letters according to their visual form, that is, their horizontal, vertical and diagonal segments.

\subsubsection{Background Knowledge}

For children to become skilled readers (Neuman and Celano, 2006), they will also need to develop a rich conceptual knowledge base and verbal reasoning abilities to understand messages conveyed through print. Successful reading ultimately consists of knowing a relatively small tool kit of unconscious procedural skills, accompanied by a massive and slowly built-up store of conscious content knowledge. It is the higher-order thinking skills, knowledge, and dispositional capabilities that enable young children to come to understand what they are reading.

\section{Research Methodology}

\subsection{Sample and Design}

This is a longitudinal study between 2008 and 2013 that monitored the reading achievement of three hundred (300) children from the Kindergarten to primary one and primary two in Ghana. The study used purposive sampling of children aged between 3-4 years and their exposure to alphabet knowledge, word recognition, nursery rhymes and lexical restructuring in their homes. They were later tested in reading and phonological awareness when aged between 5-6 years in primary one and two. One hundred were selected from urban/educated background, one hundred from suburban/semi educated homes and one hundred from rural /non-educated parents. They were recruited from five (5) Ghanaian Kindergarten that served families from a wide range of socioeconomic background to participate in the study. Parents signed an approved permission slips for their children to participate in a short in-school battery of cognitive tests. Ninety-five percent of the children were identified as Ghanaians, two percent as Nigerians, and three percent as Lebanese. One hundred and fifty (150) were males and the other one hundred (150) were females. Twenty-five percent came from single-parenting homes and the other seventy-five percent came from two-parent family background. All were normal children who were not native speakers of English. English was a second language. For forty percent (40\%) of these children, English was not the primary language spoken at home. 


\subsection{Procedure and Measures}

Questionnaires to gather data from parents of the Kindergarten children were divided into different sections which sought to measure different study variables. They were as follows: a) personal data of parents and children. Parents were asked to report information on their age, ethnicity, education, marital status, monthly income, occupation and number of children. They also reported on the focal children's age, gender, and birth order; b) home exposure to early literacy skills. Here the focus was on finding out children's exposure to early literacy skills in the homes such as: i) alphabet knowledge, ii) word recognition, iii) nursery rhymes and iv) lexical restructuring. The instrument used to measure these from the children was an adapted variant of WJIII Tests of Achievement (Woodcock, McGrew, and Mather, 2001). Mean and standard deviation scores were computed.

Two years later, the same sample of children who were now aged between 5 and 6 years in primary one and primary two were tested in a quite location during the months of May and June, 2013 along the following study variables:

\subsubsection{Reading measures}

Tests came from WJIII Tests of Achievement (Woodcock, McGrew, and Mather, 2001). i) Word attack (non-word reading): Unfamiliar non-words, which must be decoded by letter-sound correspondence rules, are read. Items progress in difficulty and the test is terminated when ceiling is reached. Split-half reliability at the age level tested here ranges from 0.92 to 0.94 ; test-retest reliability is 0.79 .; ii) Word ID (single word reading): High-frequency real words, many of which are not decodable by letter-sound correspondence rules, are read. Items progress in difficulty and the test is terminated when ceiling is reached. Split-half reliability at the age level tested here ranges from 0.97 to 0.98 ; test-retest reliability is 0.92.; iii) Passage comprehension: Children read short texts ranging from simple sentences to complex paragraphs, and respond to each by filling in a blank embedded in the text. Items progress in difficulty and the test is terminated when ceiling performance is reached. Split-half reliability at the age level tested here is 0.96 ; test-retest reliability is 0.89 .

\subsubsection{Phonological awareness measures}

Tests came from the comprehensive test of phonological processing (Wagner, Torgesen, and Rashotte, 1999): i) blending words: This 20-item subtest measures the child's ability to combine sounds to form words. The child listened to a series of tape-recorded sounds and is asked to put the sounds together to make a whole word. Items progress in difficulty and the test is stopped when the child answers three items in a row incorrectly. The internal consistency at the age level tested here ranges from 0.86 to 0.89 , and the test-retest reliability of this subtest is 0.88 .; ii) elision: This 20 item subtest measures the child's ability to say a word without saying a specific sound. For example, the child is told to say bold, and to then say bold without saying 'b'. Items progress in difficulty and the test is stopped upon three incorrect items in a row. The internal consistency at the age level tested here ranges from 0.90 to 0.92 , and the test-retest reliability of this subtest is 0.88 . ; iii) receptive vocabulary: In The peabody picture vocabulary test, 3rd edition (PPVT-III), the child hears a word on each trial, and must select the corresponding picture from among four choices. The internal consistency at the age level tested here ranges from 0.93 to 0.95 , and the test-retest reliability is 0.93 . Correlation scores between the early literacy skills at the KG from the homes and the reading and phonological awareness at the primary level were also computed.

\section{Results}

\subsection{Demographic Profile of parents of children}

The parental profile of these children shows that 25\% (constituting 75 ) were from single-parenting who were staying with single mothers and $75 \%$ (that is 225) were staying with two-parents. The mean age is 42.2 ( $\mathrm{sd}=5.96)$ for single mothers. As expected, these single mothers' households on the average showed slightly lower socioeconomic characteristics when compared with children from two-parent households nearly three times as high: mean monthly income of single mothers (US\$ 500) whereas those from two-parent households (US\$1,450). The level of education of two-parents had a mean of 10.80 years higher than single-mothers (mean 5.62). Parents who were comparatively more educated with a minimum of Bachelors degree and a maximum of postgraduate degree from the urban areas earned on the average (US\$1, 800 per month) in comparison with the non-educated parents in the rural areas who received a mean monthly 
income of US\$200 and semi-educated (maximum of high school and a minimum of Junior High) from the suburban areas who earned on the average US\$450. There was also lesser number of children in the single mother households (mean = 1.97) in comparison to the two-parent households.

8.2 Differences in early literacy skills in the homes between children of educated, semi-educated and non-educated parents.

The combined scores of children from educated, semi-educated and non-educated on the four variables that constituted early literacy skills in the homes, namely: a) alphabet knowledge, b) word recognition, c) nursery rhymes (alliterative phrases), d) lexical restructuring were summed up. The mean and the standard deviation were computed as shown in table 1 below:

Table 1: Descriptive

\begin{tabular}{lccc}
\hline Parent education background & N & Mean & Standard deviation \\
\hline Children of educated parents & 100 & 22.05 & 0.220 \\
Children of semi-educated parents & 75 & 14.89 & 0.311 \\
Children of non-educated parents & 45 & 11.51 & 1.456 \\
\hline
\end{tabular}

The means for the scores on early literacy skills (learning care services) in the home as in Table 1, show that children of educated parents had a mean of 22.050 with a standard deviation of 0.220 , children of semi-educated parents had a mean of 14.890 and a standard deviation of 0.311 , the mean and standard deviation for children of non-educated parents was found to be 11.510 and 1.456 respectively.

To test whether there is a statistically significant difference between the means, one way analysis of variance (ANOVA) was conducted. For the ANOVA test we needed to know whether the variances of the three groups are equal or not so that an appropriate test statistic and Post Hoc test would be selected for the analysis. The levene's test for equality of variances as in Table 2 indicated that there was a significant difference between the variances of the three groups of children.

Table 2: Test of Homogeneity of Variances

\begin{tabular}{cccc}
\hline Levene Statistic & $\mathrm{df1}$ & $\mathrm{df2}$ & Sig. \\
\hline 31.294 & 2 & 216 & .000 \\
\hline
\end{tabular}

That is the test for homogeneity of variances was significant with $F_{(2,216)}=31.294, p<0.05$ (two- tailed). Therefore, the Welch's $F$ was used for the ANOVA test and Games- Howell was used for the Post Hoc test.

Table 3: One-Way analysis of variance on the means Robust Tests of Equality of Means

\begin{tabular}{ccccc}
\hline & Statistic & df1 & df2 & Sig. \\
\hline Welch & 1.507 & 2 & 87.923 & .000 \\
\hline
\end{tabular}

The robust test of equality of means as seen in Table 3 shows that there was significant differences among the three groups of children in early learning care services provided in the home, $F(2,87.923)=1.507, p<0.05$ (two- tailed). Again, since the result of the test on equality of means was significant we needed to compare the three groups of children to know where the difference was. Games- Howell test was run and the result is as shown in Table 4.

The Table indicates that, on early learning care services provided in the home there is a significant difference between the mean scores of children of educated parents, and those of semi-educated and non-educated parents, $\mathrm{P}<$ 0.05 (two-tailed). There is also, a significant difference between the mean scores for children of semi-educated parents and those of non-educated parents on early learning care services provided in the home, $p<0.05$ (two-tailed). 
Table 4: Comparison of mean scores on early learning care services in the home

\begin{tabular}{llcc}
\hline & & Mean Difference & p-Value \\
\hline children of educated parents & children of semi-educated parents & 7.157 & 0.000 \\
children of educated parents & children of non-educated parents & 10.539 & 0.000 \\
children of semi-educated parents & children of non-educated parents & 3.382 & 0.000 \\
\hline
\end{tabular}

These results indicate clearly that the educational/socio-economic background of parents has considerable effects on the early learning care services such as alphabet knowledge, word recognition, nursery rhymes (alliterative phrase) provided by these parents in the home.

\subsection{Two years Later: Scores of literacy (Reading and Phonological awareness) of children of educated, semi-educated and non-educated parents}

Two years later, these same Kindergarten children who were now in Primary One and Two were tested on two linguistic variables to assess the extent to which these significant differences in early exposure to literacy skills in the homes affect their reading achievement later in the primary school. The two linguistic measures were: a) Reading Measures which included: i) word attack, ii) word identification, iii) passage comprehension and b) Phonological Awareness which comprised: i) blending words, ii) elision, iii) receptive vocabulary. The combined scores for both Reading Measures and Phonological Awareness were summed up and the mean and standard deviation were calculated as follows:

Descriptive Statistic on Reading Measure (Two Years later)

\begin{tabular}{llcc}
\hline Parent education background & N & Mean & Standard deviation \\
\hline Children of educated parents & 98 & 96.00 & 0.002 \\
Children of semi-educated parents & 86 & 55.00 & 0.013 \\
Children of non-educated parents & 78 & 48.00 & 0.021 \\
\hline
\end{tabular}

\begin{tabular}{lccc}
\multicolumn{4}{c}{ Descriptive Statistic on Phonological Awareness Measure (Two Years later) } \\
\hline Parent education background & N & Mean & Standard deviation \\
\hline Children of educated parents & 95 & 93.09 & .378 \\
Children of semi-educated parents & 84 & 49.24 & .873 \\
Children of non-educated parents & 70 & 38.37 & 1.092 \\
\hline
\end{tabular}

The above table shows that two years later, children of educated parents who had better advantage over those of semieducated, and non-educated parents at the KG level (because of early exposure to literacy skills such as: a) alphabet knowledge b) word recognition, c) nursery rhymes (alliterative phrase), d) lexical restructuring in the homes) performed better on reading achievement at Primary One and Primary Two. Similarly, children from semi-educated background performed much better than children of non-educated parents.

\section{Discussion}

The correlation results between literacy (reading and phonological achievement) in Primary One and Two and early learning care variables explain the significant differences clearly (see table below). Using Pearson correlation with significant level at the 0.01 (2-tailed), the correlation between alphabet knowledge in the homes during early learning experiences in the Kindergarten and later reading measure and phonological awareness at primary one and two were .971 and .976 respectively. Children exposed to word recognition by parents (through reading to them often in the homes during the Kindergarten period) also had .877 for reading and .909 for phonological awareness. Children exposed to lexical restructuring in the homes at the Kindergarten level by parents were more likely to have better advantage over reading measures such as word attack, word identification and passage comprehension as well as phonological awareness (with specific reference to blending of words, elision and receptive vocabulary) than those who did not have such early exposure. The correlation also showed a link between lexical restructuring and reading as .955 and phonology .962 some two years later after kindergarten. 
Correlation between Literacy (Reading and Phonological Awareness) and Early Learning Skills in the Homes (Alphabet Knowledge, Word Recognition, Nursery Rhymes, and Lexical Restructuring)

\begin{tabular}{|c|c|c|c|c|c|c|c|}
\hline & & $\begin{array}{c}\text { Alphabet } \\
\text { knowledge }\end{array}$ & $\begin{array}{l}\text { Word } \\
\text { recognition }\end{array}$ & $\begin{array}{l}\text { Nursery rhymes } \\
\text { (alliterative) }\end{array}$ & \begin{tabular}{|c|} 
Lexical \\
Restructuring
\end{tabular} & $\begin{array}{l}\text { Reading } \\
\text { measures }\end{array}$ & $\begin{array}{c}\text { Phonological } \\
\text { awareness measure }\end{array}$ \\
\hline \multirow{3}{*}{$\begin{array}{l}\text { Alphabet } \\
\text { knowledge }\end{array}$} & Pearson Correlation & 1 & $.974^{* *}$ & $.995^{* *}$ & $.998^{* \star}$ & $.971^{* *}$ & $.976^{* *}$ \\
\hline & Sig. (2-tailed) & & .000 & .000 & .000 & .000 & .000 \\
\hline & $\mathrm{N}$ & 180 & 150 & 155 & 157 & 178 & 175 \\
\hline \multirow{3}{*}{ Word recognition } & Pearson Correlation & $.974^{* *}$ & 1 & $.963^{* *}$ & $.987^{* *}$ & $.897^{\star *}$ & $.909^{* *}$ \\
\hline & Sig. (2-tailed) & .000 & & .000 & .000 & .000 & .000 \\
\hline & $\mathrm{N}$ & 150 & 245 & 185 & 149 & 221 & 210 \\
\hline \multirow{3}{*}{$\begin{array}{l}\text { Nursery rhymes } \\
\text { (alliterative } \\
\text { phrase) }\end{array}$} & Pearson Correlation & $.995^{* k}$ & $.963^{* \star}$ & 1 & $.988^{* *}$ & $.972^{* *}$ & $.982^{* *}$ \\
\hline & Sig. (2-tailed) & .000 & .000 & & .000 & .000 & .000 \\
\hline & $\mathrm{N}$ & 155 & 185 & 195 & 152 & 195 & 195 \\
\hline \multirow{3}{*}{$\begin{array}{l}\text { lexical } \\
\text { restructuring }\end{array}$} & Pearson Correlation & $.998^{* *}$ & $.987^{* k}$ & $.988^{* *}$ & 1 & $.955^{\text {*t }}$ & $.962^{* *}$ \\
\hline & Sig. (2-tailed) & .000 & .000 & .000 & & .000 & .000 \\
\hline & $\mathrm{N}$ & 157 & 149 & 152 & 157 & 155 & 152 \\
\hline \multirow{3}{*}{$\begin{array}{l}\text { Reading } \\
\text { measures }\end{array}$} & Pearson Correlation & $.971^{* *}$ & $.897^{* \star}$ & $.972^{* *}$ & $.955^{\text {t* }}$ & 1 & $.998^{* *}$ \\
\hline & Sig. (2-tailed) & .000 & .000 & .000 & .000 & & .000 \\
\hline & $\mathrm{N}$ & 178 & 221 & 195 & 155 & 262 & 249 \\
\hline \multirow{3}{*}{$\begin{array}{l}\text { Phonological } \\
\text { awareness } \\
\text { measure }\end{array}$} & Pearson Correlation & $.976^{* *}$ & $.909^{* *}$ & $.982^{* *}$ & $.962^{* *}$ & $.998^{* *}$ & 1 \\
\hline & Sig. (2-tailed) & .000 & .000 & .000 & .000 & .000 & \\
\hline & $\mathrm{N}$ & 175 & 210 & 195 & 152 & 249 & 249 \\
\hline
\end{tabular}

These findings suggest answers to the first and second research questions of this study, namely: 1) What specific strategies are successful in improving children's language and literacy skills during the preschool years and beyond? and 2) What is the relationship between early childhood literacy experiences and later reading acquisition? In other words, how are early literacy and oral language related? In answer to the first question, the study indicated a synergy between home/parental background and parental strategies such as exposing children early enough to alphabet knowledge in the homes, showing them how to recognize words and sounds through regular reading, communicating more often with children, teaching them alliterative phrases (nursery rhymes) as well as helping them to differentiate meanings between words that have similar sounds such as 'cat' and 'cut'(lexical restructuring) etc. All this had tremendous impact on later linguistic abilities on reading measures in identifying words, attacking words and passage comprehension in reading achievement at the primary level. On the other hand, children from less endowed homes and from less educated parents' correlated scores on reading measures and the phonological awareness, indicated a deficit in linguistic skills compared to those who had earlier literacy exposure in the homes as indicated in the correlation results above.

This data confirm other studies that reading stories to children on a regular basis constitutes one of the more potent supports for literacy learning (Bus, Vanljzendoorn, and Pellegrini, 1995). Indeed, Dickinson and Smith, 1994, Whitehurst and Lonigan, 1998, have also shown that a parent's style or approach to reading storybooks to children has both short-term and long-term effects on language and literacy development. Shared book reading activities, such as dialogic reading (Whitehurst et al., 1994), for example, and repeated readings (Biemiller, 2006) have been widely studied and identified as an important source of knowledge about vocabulary, about letters, and about the characteristics of written language. Recent studies (Beck and McKeown, 2007; Duke, 2000) have also highlighted the importance of introducing children to a wide variety of books in different genres such as information books, poetry, and popular folk tales.

Again the findings of this study indicate a synergy between early childhood literacy experiences and later reading acquisition specifically on rimes and phonemes. Children from educated and semi-educated backgrounds with exposure to early home literacy experiences from parents were more likely than children from indigent background with little English in the home to perform significantly better. The former did better on phonological segments of spoken language such as words, syllables, rimes and phonemes more than the latter. (cf. Anthony J et al, 2003). It is in this context that massive body of recent research such as Burgess,(2006) and Lonigan, (2006), Ehri and Roberts (2006) all make the conclusion that phonological awareness is a critical precursor, correlate, and predictor of children's reading achievement. Discriminating units of language (i.e., words, segments, and phonemes) is strongly linked to successful reading (cf. US National Reading Panel Report, 2000). The results of this study corroborate these earlier studies. Children in Primary 
One and Two in this study who performed better on phonological awareness were mostly from the educated and better endowed background exposed earlier to literacy skills in the homes.

Again the data offer support to the third research question on the type of home environment: What types of home literacy activities are children exposed to and how do these early experiences contribute to early literacy and later reading acquisition? Thus the home organization and structure can play a major role in promoting critical skills for literacy development. These findings showed that home environments structured to have play materials, literacy tools and a wide access to books (such as children from educated parents compared to children from uneducated home backgrounds) significantly performed better on later reading and phonological awareness. This indicates the home setting as likely to exert influence on the child's patterns of activities and engagements. This confirms considerable number of studies (Morrow, 1990; Neuman and Roskos, 1992, 1997; Vukelich, 1994) that have underscored the powerful influence of access to literary tools on young children's engagement in literacy activities. Thus early exposure to literary tools has resulting effects on literacy improvement. Children are likely to use space and its boundaries to regulate and guide their own responses and to use these more intimate settings to interact in longer and richer conversation with others (Neuman and Roskos, 1997).

\section{Conclusion}

The first five years of life are crucial to a child's lifelong literacy development. Young children's earliest experiences and environments set the stage for future development and success in school and life. Children, who arrive in kindergarten with a foundation of pre-literacy skills, and the interest and motivation to learn, are better pre-pared for the complex task of learning to read than those who lack these foundational skills (Wasik, Bond, and Hindman, 2006). These earliest experiences from the homes become organized or structured into schemas. These schemas become the building blocks providing children with the conceptual apparatus for making sense of the world around them by classifying incoming bits of information into similar groupings (Anderson and Pearson, 1984). Well-read to children internalize a form of story grammar, a set of expectations of how stories are told which enhances their understanding. Knowledge becomes easier to access (Neuman, 2001), producing more knowledge networks. And those with a rich knowledge base find it easier to learn and remember.

Most children in urban Ghana in the years before they enter school experience a supportive home and may have access to early home literacy skills as well as resources that support healthy development and school readiness. On the other hand, many other children mostly from the rural parts of the country who come from non-educated home backgrounds may not be so fortunate. Thus, these patterns of early disparities in childhood have the potential of carrying over into early education and beyond that can affect the primary academic achievement as revealed by the findings of this longitudinal study. For example, the report that in Ghana, Reading achievement levels as measured by the Government-administered Criterion Referenced Test in 2000 showing that fewer than 10\% of the school children at primary level six in the public schools are able to read with grade level mastery are likely to be symptomatic of these early disparities.

The findings of this paper reveal that low reading ability generally tends to be typical with young children from less endowed and less educated background in the early child care education. Children with low reading ability at primary one and primary two in this study were mostly those who lacked access to earlier experiences in the homes at the Kindergarten level such as access to books, literacy tools, play materials etc. This precipitated the significant differences in performance between the different categories of children.

Consequently the data of this study suggest that to bridge the knowledge-gap in Ghana, there is the need for levelling the playing field for low income rural children. Public nurseries, day care centres and kindergarten schools especially in deprived communities are to be better resourced to make up for the early home disparities in early child care education that are likely to be carried over into academic achievements in the primary schools. This paper corroborates other findings in Ghana: Basic Education Certificate Examination results since 2005 consistently indicate a fall in English language performance from the public rural basic schools when compared with children from the private urban basic schools (cf. 2007 Annual Report: West Africa Examinations Council). This is indicative of the social class gap between family backgrounds and early childhood disparity. 


\section{References}

Anderson, R. C., \& Pearson, P. D. (1984). A schema-theoretic view of basic processes in reading comprehension. In P. D. Pearson (Ed.), Handbook of reading research (pp. 255-291). NY: Longmann.

Anthony J, Lonigan C, Driscoll K, Phillips B, Burgess S. (2003). Phonological sensitivity: a quasi-parallel progression of word structure units and cognitive operations. Read Res Q 2003;38:470-487

Beck, I. \& McKeown, M. (2007). Increasing young low-income children's oral vocabulary repertoires through rich and focused instruction. Elementary School Journal, 107, 251-271.

Biemiller, A. (2006). Vocabulary development and instruction: A prerequisite for school learning. In D.Dickinson \& S. B. Neuman (Eds.), Handbook of early literacy research (Vol. II, pp. 41--51). New York: Guilford.

Bloom, L. (1970). Language development: Form and function in emerging grammars. Cambridge,MA: The M.I.T. Press.

Bond, G., \& Dykstra, R. (1967). The cooperative research program in first-grade reading instruction. Reading Research Quarterly, 2, 5142.

Burgess, S. (2006). The development of phonological sensitivity. In D.Dickinson \& S. B. Neuman (Eds.), Handbook of Early Literacy Research: Volume II (Vol. II, pp. 90-100). New York: Guilford Press.

Bus, A., \& Van ljzendoorn, M. (1995). Mothers reading to their 3-year-olds: The role of mother-child attachment security in becoming literate. Reading Research Quarterly, 30, 998-1015.

Bush, G. W. (2002, April 3). President, Mrs. Bush promote early childhood education initiative. Speech posted by the Office of the Press Secretary. Retrieved July 6, 2005, from http://www.whitehouse.gov/news/releases/ 2002/04/20020403-6.html

Chall, J., Jacobs, V. \& Baldwin, L. (1990). The reading crisis: Why poor children fall behind. Cambridge, MA: Harvard University Press.

Chief Examiners' Report for the Basic Education Certificate Examination (2007). Annual Report The West African Examinations Council.

Dickinson, D., \& Neuman, S. B. (Eds.). (2006). Handbook of early literacy research. New York, NY: Guilford Press

Dickinson, D., \& Smith, M. (1994). Long-term effects of preschool teachers' book readings on low-income children's vocabulary and story comprehension. Reading Research Quarterly, 29, 104-122.

Dickinson, D., McCabe, A., Anastasopoulos, L., Peisner-Feinberg, E. S., \& Poe, M. D. (2003). The comprehensive language approach to early literacy: The interrelationships among vocabulary, phonological sensitivity, and print knowledge among preschool-aged children. Journal of Educational Psychology, 95, 465-481.

Duke, N. (2000). For the rich its richer: Print experiences and environments offered to children in very low- and very-high socioeconomic status first-grade classrooms. American Educational Research Journal, 37, 441-478.

Ehri, L. C. (1979). Linguistic insight: Threshold of reading acquisition. In T.G. Waller \& G. F. MacKinnon (Eds.), Reading research: Advances in theory and practice (Vol. 1, pp. 63-111). New York: Academic Press.

Ehri, L., \& Roberts, T. (2006). The roots of learning to read and write: Acquisition of letters and phonemic awareness. In D.Dickinson \& S. B. Neuman (Eds.), Handbook of Early Literacy Research (pp. 113-134). New York: Guilford Press.

Ghartey Ampiah, J (2010). Quality Basic Education in Ghana: Prescription, praxis and problems. Paper Delivered at the Experience Sharing Seminar, 17-19 January 2010, Erata Hotel Accra.

Gibson, E., \& Levin, E. (1975). The psychology of reading. Cambridge, MA: M.I.T. Press.

Goswami, U. (2001). Early phonological development and the acquisition of literacy. In S. B. Neuman \& D. Dickinson (Eds.), Handbook of Early Literacy Research (pp. 111-125). New York: Guilford.

Lonigan, C. (2006). Conceptualizing phonological processing skills in pre-readers. In D.Dickinson \& S. B. Neuman (Eds.), Handbook of Early Literacy Research: Volume II (Vol. II, pp. 77-89). New York: Guilford.

Maclean, M., Bryant, P., \& Bradley, L. (1987). Rhymes, nursery rhymes, and reading in early childhood. Merrill-Palmer Quarterly, 33, 255-281.

Metsala, J. (1999). Young children's phonological awareness and nonword repetition as a function of vocabulary development. Journal of Educational Psychology, 91, 3-19.

Ministry of Education, Science and Sports [MoESS] (2008). Education Sector Report. Accra: MoESS

Morrow, L. M. (1990). Preparing the classroom environment to promote literacy during play. Early Childhood Research Quarterly, 5 , 537-554

National Academy Press Bush, G. W. (2002, April 3). President, Mrs. Bush promote early childhood education initiative. Speech posted by the Office of the Press Secretary. Retrieved July 6, 2005, from http://www.whitehouse.gov/news/releases/ 2002/04/20020403-6.html

National Association for the Education of Young Children and National Council of Teachers of Mathematics. (2002). Math experiences that count! Young Children, 57, 60-62.

National Reading Panel Report. (2000). Teaching children to read. Washington, D.C.: National Institute of Child Health and Development.

Neuman, S. B. (2001). The role of knowledge in early literacy. Reading Research Quarterly, 36, 468-475.

Neuman, S. B., \& Celano, D. (2006). The knowledge gap: Implications of leveling the playing field for low-income and middle-income children. Reading Research Quarterly, 41, 176-201

Neuman, S. B., \& Dickinson, D. (2001). Handbook of early literacy research. New York: Guilford.

Neuman, S. B., \& Roskos, K. (1992). Literacy objects as cultural tools: Effects on children's literacy behaviors in play. Reading Research Quarterly, 27, 202-225. 
Neuman, S. B., \& Roskos, K. (1997). Literacy knowledge in practice: Contexts of participation for young writers and readers. Reading Research Quarterly, 32, 10-32.

Okagaki, L., \& Steinberg, R. (1993). Parental beliefs and children's school performance. Child Development, 64, 36-56.

Roskos, K., \& Vukelich, C. (2006). Early literacy policy and pedagogy. In D. Dickinson \& S. B. Neuman (Eds.), Handbook of early literacy research (Vol. II, pp. 295-310). New York: Guilford.

Scarborough, H. (2001). Connecting early language and literacy to later reading (dis)abilities: Evidence, theory, and practice. In S. B. Neuman \& D. Dickinson (Eds.), Handbook of Early Literacy Research (pp. 97-110). New York: Guilford.

Shonkoff, J. and Phillips, D., eds. (2002). From Neurons to Neighborhoods: The Science of Early Childhood Development. Washington, DC: National Academies Press. www.nap.edu,

Snow, C. E., Burns, M. S., \& Griffin, P. (Eds.). (1998). Preventing reading difficulties in young children. Washington DC: National Research Council,

Thompson, R. (Spring/Summer 2001). Development in the First Years in The Future of Children: Caring for Infants and Toddlers, Vol. 11, No.1. www.futureofchildren.org

Vukelich, C. (1994). Effects of play interventions on young children's reading of environmental print. Early Childhood Research Quarterly, 9, 153-170.

Wagner, R. K., Torgesen, J. K., \& Rashotte, C. A. (1999). Comprehensive test of phonological processing. Austin, TX: Pro-Ed.

Wasik, B., Bond, M. A., \& Hindman, A. (2006). The effects of a language and literacy intervention on Head Start children and teachers. Journal of Educational Psychology 98, 63-74.

Whitehurst, G., \& Lonigan, C. (1998). Child development and emergent literacy. Child Development, 69, 848-872.

Whitehurst, G. J., Epstein, J. N., Angell, A. L., Payne, A. C., Crone, D. A., \& Fischel, J. (1994). Outcomes of an emergent literacy intervention in Head Start. Journal of Educational Psychology, 86, 542-555.

Woodcock, R. W., McGrew, K. S., \& Mather, N. (2001). WJ III tests of cognitive abilities. Itasca, IL: Riverside Publishing. 
ISSN 2239-978X

ISSN 2240-0524
Journal of Educational and Social Research MCSER Publishing, Rome-Italy
Vol. 4 No. 6 September 2014 